\title{
TERJEMAH AL-QURAN QURAISH SHIHAB PADA AYAT PRODUKSI, DISTRIBUSI, DAN KONSUMSI
}

\author{
Istianah $^{1}$, Mintaraga Eman Surya ${ }^{2}$ \\ ${ }^{1}$ Program Studi Hukum Ekonomi Syariah, FAI Universitas Muhammadiyah Purwokerto, Email : \\ istianahmrum@gmail.com \\ ${ }^{2}$ Program Studi Hukum Ekonomi Syariah, FAI Universitas Muhammadiyah Purwokerto. Email: \\ mintaragaesurya@gmail.com
}

\begin{abstract}
ABSTRAK
Quraish Shihab adalah salah satu ulama era kini yang telah menerjemahkan al-Quran dalam karya "Al-Quran dan Maknanya." Permasalahan yang hendak dijawab melalui penelitian ini adalah tentang hakikat terjemah al-Quran menurut Quraish Shihab, metode dan aturan yang digunakan oleh Quraish Shihab dalam menerjemahkan al-Quran, terjemah al-Quran Quraish Shihab dalam menjelaskan makna ayat-ayat tentang produksi, distribusi, dan konsumsi. Penelitian ini menggunakan metode analisis kualitatif dengan merujuk langsung kepada karya Shihab dan kitab yang menjadi sumber rujukan Shihab. Melalui kajian ini ditemukan bahwa Shihab menggunakan metode terjemah tafsiriyyah di mana proses penerjemahannya berbasis tafsir, dapat juga disebut dengan metode ma'nawiyah (makna). Quraish Shihab menyadari bahwa makna hakiki dari ayat-ayat al-Quran hanya dapat dicapai oleh pengucapnya sendiri, sehingga perbedaan dan keanekaragaman terjemah al-Quran merupakan hal wajar. Makna dan terjemah ayat produksi, distirbusi, dan konsumsi memberikan pemahaman tentang konsep dan empat prinsip ekonomi, yaitu prinsip tauhid, keseimbangan, kehendak bebas, dan tanggungjawab.
\end{abstract}

Kata kunci: Terjemah al-Quran; Quraish Shihab; Ayat Produksi; Ayat Distribusi; Ayat Konsumsi.

\begin{abstract}
Quraish Shihab is one of the scholars of the current era who has translated the Koran into the work "Al-Quran and it's Meaning." The problem to be answered through this research is about the nature of the translation of the Koran according to the Quraish Shihab, the methods and rules used by the Quraish Shihab in translating the Koran, the translation of the Koran Quraish Shihab in explaining the meaning of the verses about production, distribution, and consumption. This study uses a qualitative analysis method by referring directly to the work of Shihab and the book that is the source of Shihab references. Through this study, it was found that Shihab used the tafsiriyyah method where the translation process was based on interpretation, it could also be called the ma'nawiyah (meaning) method. Quraish Shihab realizes that the essential meaning of the verses of the Koran can only be achieved by the speaker himself so that the differences and diversity of the translation of the Koran are natural. The meanings and translations of the verses of production, distribution, and consumption provide an understanding of the concepts and four economic principles, namely the principle of monotheism, balance, free will, and responsibility.
\end{abstract}

Keywords: Translation of the Quran; Quraish Shihab; Production Verses; Distribution Verses; Consumption Verses. 


\section{Islãmadîna

\section{PENDAHULUAN}

Problematika penerjemahan teks suci -demikian juga dengan kitab suci selain al-Quran- yang berulang kali menjadi pembahasan tanpa henti yaitu bahwa sebaik apapun proses interpretasi - di mana sebagai tahap awal dari proses penerjemahantersebut dilakukan, tidak dapat mencapai kebenaran dan hasil final yang absolut. Kunci permasalahan adalah, bagaimana teks atau tulisan suci -yang berisi konsep ketuhanan, hal-hal gaib dan semacamnya- dapat ditafsirkan dan diterjemahkan ke dunia manusia, terlebih lagi pada abad ini (Charlesworth: 2012), sementara itu firman Allah Swt tidak dapat direproduksi ke dalam perkataan manusia (Abdul Raof: 2013). Bersamaan dengan kebutuhan akan terjemah al-Quran, ulama tidak dalam satu pendapat mengenai kebolehan al-Quran untuk diterjemahkan. Perbedaan pendapat tersebut kemudian bertemu pada titik kesepakatan, bahwa bagaimanapun al-Quran dan ke-i'jazan-nya dari segi bahasa menjadikannya istimewa dalam hal penerjemahan, dan mereka pun sepakat bahwa terjemah al-Quran bukanlah al-Quran dan tidak boleh disebut sebagai al-Quran (Sabri, $1351 \mathrm{H}:$ 7-8) dan terjemah al-Quran merupakan bagian dari tafsir sehingga boleh dilakukan (Rohmana, 2015: 179).

Problematika seputar terjemah al-Quran dan pemilihan metodenya juga terjadi di Indonesia, salah satunya yaitu penolakan oleh tokoh lokal di Batavia pada awal abad XX. Meskipun demikian, penerjemahan al-Quran tetap dilakukan pada abad itu sampai saat ini, baik ke dalam bahasa Indonesia maupun berbahasa daerah. Menurut Muchlis Hanafi ada sekitar 20 karya terjemah (Hanafi, 2011: 178-179), sedangkan menurut Jajang A Rohmana terjemah berbahasa Sunda ditemukan 19 karya (Rohmana, 2015: 180-181), sehingga tidak menutup kemungkinan jumlah terjemah al-Quran di Indonesia mencapai jumlah yang tidak sedikit.

Quraish Shihab (selanjutnya akan disebut dengan Quraish) merupakan salah satu sarjanawan sekaligus ulama Indonesia pada era kini yang sangat produktif menghasilkan karya seputar kajian al-Quran, termasuk terjemah dan tafsirnya. Karya beliau mencapai 50 judul buku (http://www.pktafsirquran.com) dan dikatakan bahwa ia merupakan salah satu pelopor maraknya kajian al-Quran di Indonesia dewasa ini, khususnya dalam bidang tafsir maựu'i (Istianah, 2016: 43).

Penelitian ini, akan mengangkat salah satu karya Quraish tentang terjemah al-Quran, yaitu "Al-Quran dan Maknanya" (selanjutnya akan disebut QMQ) yang diterbitkan pertama kali pada 2010. Akan tetapi, pada pendahuluankarya tersebut Quraish menyatakan bahwa karya tersebut sejatinya bukanlah karya terjemah al-Quran (Shihab, 2013: i). Penelitian ini akan mengkaji hakikat terjemah dan metode yang digunakan oleh Quraish pada penyusunan QMQ, apakah merupakan metode ḥarfiyah 
ataukah tafsiriyah. Penelitian ini juga akan menganalisa terjemah ayat seputar tema produksi, distribusi, dan konsumsi. Karena dalam era yang semakin berkembang ini, manusia sangat membutuhkan guideline kehidupan dalam setiap aspek kehidupan, termasuk bidang ekonomi, yang bersumber dari teks suci yang mudah dipahami.

Terjemah dalam pengertian umum adalah ta'bir makna kalam dalam suatu bahasa (bahasa sumber/BSu) menggunakan kalam lain dari bahasa lain (bahasa sasaran/BSa) dengan tetap menjaga seluruh makna asal dan maksud-maksudnya (Al-Zarqani, 1995: 91). Pemindahan bahasa ke dalam bahasa lain tersebut, dalam pandangan al-Zahabi dapat dilakukan dengan tanpa menjelaskan makna yang dikandung oleh $\mathrm{BSu}$ dan adakalanya merupakan interpretasi dan penjelasan makna menggunakan bahasa lain (al-Zahabi, 2000: I, 19). Menurut Newmark, terjemah merupakan penyampaian makna teks dari suatu bahasa ke dalam bahasa lain sesuai dengan maksud penulis teks (Newmark, 1988: 5).

Terjemah dibagi ke dalam dua macam, yaitu terjemah harfiyah atau lafziyah dan terjemah tafsiriyah atau ma'nawiyah. Terjemah harfiyah atau lafziyah yaitu terjemah yang tetap menjaga kesamaan bahasa sasaran dengan bahasa sumber dalam susunan dan sitematikanya. Langkahnya seperti meletakkan kata (BSa) pada posisi kata yang searti (BSu) (al-Zarqani, 1995: 93 dan al-'Alusy, 2007: 21-30), sedangkan terjemah tafsiriyah tidak menjaga kesamaan tersebut karena yang terpenting dalam terjemahan ini adalah keindahan dalam mendeskripsikan makna dan sampainya tujuan kalimat secara sempurna. Oleh karena itu, jenis terjemah yang satu ini disebut juga dengan terjemah ma'nawiyah, disebut tafsïriyah karena lebih mengedepankan unsur keindahan deskriptif-imajinatif makna dan maksud tujuan kalimat yang membuatnya serupa dengan tafsir walaupun bukanlah tafsir (Al-Zarqani, 1995: 92).

Kajian tentang terjemah al-Quran semakin giat dilakukan baik oleh para sarjana dalam dan luar negeri, insider maupun outsider Islam. Stefan Wild mengkaji tentang terjemah al-Quran ke bahasa Inggris (Stefan Wild, 2015: 158-182), Haleem menganalisa bagaimana konteks sangat berperan dalam interpretasi dan terjemah al-Quran ke dalam bahasa lain (Haleem, 2018: 47-66). Strategi penerjemahan yang dapat memberikan implikasi makna yang berbeda-beda dikaji oleh Eggen untuk menemukan konseptualisasi Islam dalam terjemah al-Quran (Eggen, 2016: 49-91). Sementara itu, Abdul Raof menyusun buku tentang wacana, tekstur, dan penafsiran dalam terjemah al-Quran (Raof: 2013).

Dalam konteks keindonesiaan, terdapat kajian oleh Egi Sukma Bihaki (Baihaki: 2017) tentang proses penerjemahan al-Quran ke bahasa Indonsia, Johanna Pink mengkaji tentang permasalahan teologi dan kontroversinya dalam terjemah al-Quran 
berbahasa Indonesia (Pink, 2015: 100-120), hal tersebut rupanya menjadi sesuatu yang lazim terjadi pada terjemah kitab suci (Arichea, 1990: 40-68). Syahrullah mengkaji tentang terjemah ke bahasa Indonesia menggunakan metode tafsiriyah di mana dalam hasil terjemah terjadi distorsi makna (Syahrullah, 2013: 43-62), artikel yang terkait yaitu publikasi oleh Istianah (2016) tentang polemik karya terjemah karya H.B. Jassin dan Muhammad Thalib dan kritik atas koreksi Muhammad Thalib terhadap al-Quran Terjemah yang diterbitkan oleh Kementrian Agama RI (Istianah: 2015).

Kajian mengenai pemikiran dan tafsir Quraish pada cakupan bidang ekonomi, sebenarnya sudah banyak dilakukan oleh para peneliti Indonesia, di antaranya yaitu tentang konsep at-tijarah oleh Andi Zulfikar (Zulfikar: 2017), Cut Fauziah (Fauziah: 2017), dan oleh Andi Zulfikar Darussalam, Ahmad Dahlan Malik, dan Ahmad Hudaifah (Darussalam: 2017). Pemikirannya tentang prinsip dan tafsir ayat-ayat ekonomi dikaji oleh Rizki Syahputra (Syahputra: 2014) dan Muhammad Iswadi (Iswadi: 2013).

\section{METODE PENELITIAN}

Penelitian ini adalah penelitian pustaka (Hadi, 1994: 3), data primer yang disajikan adalah karya Quraish tentang terjemah Al-Quran, yaitu Al-Quran dan Maknanya terbitan 2013, Tafsir al-Mishbah, dan karya-karya beliau yang lain yang berkaitan, serta kitab-kitab tafsir yang menjadi rujukan utamanya. Pengumpulan data dilakukan dengan merujuk langsung kepada karya terjemah dan kitab tafsir. Metode yang digunakan dalam menganalisa data penelitian ini adalah metode kualitatif dengan menggunakan pendekatan tafsir dan bahasa sebagai kerangka dasarnya. Pendekatan tafsir ditempuh untuk mengetahui maksud penerjemah dalam memaknai ayat sekaligus melihat kesesuaian terjemah ayat dengan makna dan tafsirnya, sedangkan pendekatan bahasa untuk melihat kesesuaian hasil terjemah dari segi kebahasaan. Data-data tersebut kemudian disoroti secara cermat dengan metode induktif-deduktif.

\section{HASIL DAN PEMBAHASAN}

Teks al-Quran, menurut Quraish, pada hakikatnya tidak seperti teks lain ketika diterjemahkan. Hal yang paling memungkinkan untuk dilakukan dalam penerjemahan al-Quran adalah menerjemahkan sebagian makna-makna ayat al-Quran. Quraish menyatakan, bahwa karyanya -Al-Quran dan Maknanya-

Ia bukan terjemahan al-Qur'an karena pada hakikatnya, sebagaimana yang ditegaskan oleh banyak ulama, al-Qur'an tidak dapat diterjemahkan dalam arti dialih bahasakan (Shihab, 2013: iv).

Quraish -dalam pembukaan karyanya- memungkiri bahwa karyanya merupakan terjemah al-Quran, akan tetapi sesuai definisi al-Zarqani dan al-Zahabi, karya tersebut dapat digolongkan ke dalam karya terjemah al-Quran. Pernyataan Quraish -besar 
kemungkinan- dilatarbelakangi oleh kesadarannya tentang hakikat Bahasa Arab dan hakikat al-Quran sebagai kalam Ilahi. Maka yang dilakukan bukanlah menerjemahkan kata melainkan makna-makna yang terdapat dalam ayat melalui proses penafsiran sebagaimana yang dilakukan oleh Wiranatakoesomah (Rohmana, 2015: 197)

Menurut Quraish, penerjemahan yang dimaksud tidak dapat ditempuh pada keseluruhan ayat, demikian juga dengan hasil pemaknaan masih dalam batasan sudut pandang manusia sehingga tidak dapat mencapai makna hakiki (Shihab, 2013: iii). Ia menyadari bahwa pemahaman tentang makna dari setiap redaksi ayat-ayat al-Quran bagi yang mendengar dan yang membacanya adalah relatif, sedangkan makna hakiki hanya dapat dicapai oleh pengucapnya sendiri, yaitu Allah Swt (Shihab, 2015: 29). Maka tak heran jika terdapat keanekaragaman penafsiran sebagaimana sudah terjadi di antara para sahabat Nabi Muhammad (Shihab, 1997: 75), dan -tentu sajamemungkinkan juga adanya keanekaragaman penerjemahan kitab suci ini.

Melalui judul karyanya, “Al-Quran dan Maknanya,” Quraish menegaskan bahwa penerjemahan yang ia tempuh merupakan penerjemahan terhadap makna al-Quran. Karya tersebut (selanjutnya disebut QMS) terbit pertama kali pada tahun 2010 sebenarnya merupakan karya ringkas yang bersumber pada Tafsir al-Misbah yang terdiri dari 15 jilid, ia pun melibatkan Tafsir al-Muntakhab sebagai rujukan dalam menjelaskan pembahasan ilmiah dari ayat-ayat yang diterjemahkan. Tafsir al-Muntakhab adalah kitab tafsir yang disusun oleh sejumlah pakar tafsir dari Mesir ini sebelumnya telah menjadi salah satu rujukan karya tafsir Quraish (Shihab, 2013: vi). Melihat sumber dan rujukan tersebut, dapat dikatakan bahwa Quraish menggunakan metode terjemah tafsiriyyah. Tarjamah tafsïriyyah yaitu penafsiran al-Qur'an dengan makna terdekat kemudian menerjemahkan hasil penafsiran tersebut ke dalam bahasa lain (al-Qattan, 2000: 327).

Sebagai pakar kajian al-Quran, Quraish mengharuskan seorang penerjemah al-Quran menguasai makna-makna dari setiap kata dalam bahasa sumber (Bsu) dan memilih kata dalam bahasa sasaran (Bsa) yang sepadan berikut dengan kandungannya. Hal tersebut dilakukan untuk menghindari kesalahan baik berupa kekurangan ataupun kelebihan makna (Shihab, 2013: iv). Quraish secara rinci menentukan syarat-syarat dalam menerjemahkan al-Quran dengan mengikuti fatwa al-Azhar Mesir dengan tetap mengakui bahwa upaya tersebut bukan jaminan dirinya tak luput dari kesalahan. Syarat-syarat yang dimaksud di antaranya: 1) menghindari istilah teknis dan pembahasan ilmiah kecuali yang dibutuhkan untuk pemahaman ayat; 2) tidak menguraikan teori ilmiah; 3) pembahasan luas yang dibutuhkan untuk pemahaman makna ayat dituliskan pada catatan kaki; 4) terlepas dari madzhab tertentu baik madzhab fikih maupun ilmu kalam; 5) menggunakan Qira'at Hafesh dalam memetik 
makna ayat; 6) tidak memaksakan hubungan ayat yang satu dengan yang lainnya; 7) menjelaskan jumlah ayat dan kategori makiyyah dan madaniyyah ayat (Shihab, 2013: iv). Sedangkan sebagai modal dasar penerjemah, ia menekankan sikap ikhlas dan kejernihan motivasi penerjemah untuk memahami maksud firman Allah, sikap rendah hati dan kehati-hatian dalam menarik pesan ilahi (Shihab, 2015: 22-27).

Selain kaidah dan syarat di atas, Quraish juga menetapkan hal lainnya, ia menerjemahkan kata atau kalimat yang mengandung majāz, isti'ārah, dan tasybīh sebagaimana kata yang sebenarnya, seperti pada terjemah QS. al-Isra/17: 29-30 yang membahas tentang anjuran dalam melakukan konsumsi. Quraish menerjemahkan kalimat "yadaka maghlūlah ilā "unukika" dengan "tanganmu terbelenggu ke lehermu" yang maksudnya adalah sikap kikir. Quraish mungkin bermaksud untuk tetap menghadirkan keindahan bahasa al-Quran dan menjaga keutuhan tujuan dan fungsi dari ketiga hal tersebut, misalnya tasybih, tetap dibuat utuh untuk menampilkan penggambaran yang lebih jelas dan konkret baik dari segi sifat dan keadaannya serta menggambarkan hal-hal yang immaterial menjadi bersifat material (Shihab, 2015: 148-150).

Teks hasil terjemah kemudian disuguhkan menggunakan model sisipan kalimat. Teks/kalimat hasil interpretasi penerjemah berfungsi sebagai uraian yang dapat memperjelas makna ayat (Shihab, 2013: iv). Teks tersebut tetap dapat dibedakan dari teks terjemah asal karena dipisahkan menggunakan "tanda kurung". Hal itu ia lakukan karena melihat bahasa al-Quran yang cenderung singkat dan sarat makna dan dalam hal ini tampaknya Quraish mengikuti metode ulama klasik dalam hal teknis penulisan tafsir.

Penjelasan makna dan kandungan secara umum dari keseluruhan surat dalam al-Quran diletakkan pada bagian akhir karya, berikut dengan penjelasan tema dan tujuan utama masing-masing surat dan didahului dengan pemabahasan tajwid secara singkat (Shihab, 2013: 1-60). Pada setiap terjemah surat terdapat catatan kaki yangberfungsi sebagai penjelas dan terdapat keterangan ayat-ayat yang memiliki asbāb al-nuzūl.

Menurut Amin Suma, ayat tentang produksi sebanyak 5 ayat, ayat tentang distribusi sebanyak 3 ayat, dan ayat tentang konsumsi sebanyak 4 ayat (Suma, 2002: 96-118). Quraish sendiri tidak menyebutkan secara eksplisit yang mana saja termasuk dalam kategori ayat-ayat tersebut, penelitian ini mencoba menelusuri ayat-ayat yang terkait dengan pembahasan produksi, distribusi dan konsumsi kemudian mengklasifikasikannya ke dalam tiga bidang. 
Tabel 1. Data ayat al-Quran seputar produksi, distribusi, konsumsi

\begin{tabular}{llll}
\hline No. & Ayat-ayat Produksi & \multicolumn{1}{c}{ Ayat-ayat Distribusi } & Ayat-ayat Konsumsi \\
\hline & & & \\
1. & QS. al-Nahl/16: 5-9 & QS. al-Hasyr/59: 7 & QS. al-Baqarah/2: 168 \\
2. & QS. al-Hadid/ 57: 25 & QS. al-Taubah/9: 34 & QS. al-Baqarah/2: 172 \\
3. & & & QS. al-A'raf/7: 31 \\
4. & & QS. al-A'raf/7: 32 \\
5. & & QS. al-Nahl/16: 114 \\
6. & & QS. al-Isra/17: 29-30 \\
7. & & QS. al-Mu'minun/23: 51 \\
\hline
\end{tabular}

\section{Terjemah Quraish Shihab terhadap Ayat Al-Quran tentang Produksi}

a. QS. al-Nahl/16: 5-8

Dan binatang-binatang ternak telah Dia ciptakan untuk kamu; padanya ada (bulu dan kulit untuk pakaian) yang menghangatkan dan berbagai manfaat (lainnya) dan sebagian darinya kamu makan. Dan kamu memperoleh keindahan padanya, ketika kamu membawanya kembali (ke kandang) dan ketika kamu melepaskannya (ke tempat gembalaan). Dan ia (binatang ternak) memikul beban-beban kamu ke suatu negeri (yang akan kamu kunjungi) yang (jaraknya begitu jauh sehingga) kamu tidak sanggup mencapainya (dengan memikul beban itu atau bahkan tanpa beban) melainkan dengan susah payah (yang menyulitkan diri). Sesungguhnya Tuhan Pemelihara kamu benar-benar Maha Penyayang, lagi Maha Pengasih. Dan (Allah swt. juga telah menciptakan) kuda, begal, dan keledai, supaya kamu menungganginya dan (sebagai) perhiasan. Dan Dia menciptakan apa yang kamu tidak mengetahuinya (saat ini, tetapi kelak kamu mengetahui) (Shihab, 2013: 267-268).

Pada tafsir ayat ini, Quraish lebih fokus terhadap pembahasan tentang penciptaan binatang ternak dan manfaatnya berupa bulu dan kulit yang menghangatkan, manfaat lain -tanpa menguraikan macam dari manāfi', (manfaat-manfaat) lainnya-, makanan, dan keindahan, dari pada mengaitkannya dengan kegiatan produksi, demikian juga dengan Tafsir al-Muntakhab (Lajnah, tt: 1, 440), sedangkan Syeikh al-Razi menyebutkan sekilas tentang manfaatnya dalam jual beli dalam tafsir ayat 5 (al-Razi, tt: 9, 350). Ayat tersebut menyebutkan kata di'fun (sesuatu yang menghangatkan baik pakaian atau kemah yang terbuat dari kulit, bulu, atau rambut binatang) di mana mengiisyaratkan adanya proses produksi dari bahan baku yang berasal dari kekayaan alam menjadi pakaian. Kekayaan alam ini menjadi salah satu rumus dalam fungsi produksi (hubungan antara faktor dengan tingkat produksi) di mana Q (jumlah produksi) merupakan hasil dari faktor jumlah stok modal, tenaga kerja, kekayaan alam, dan tingkat teknologi (Rozalinda, 2017: 113).

Quraish kemudian membahas -maksud ayat 7 dan 8- tentang manfaat dari 
binatang tersebut sebagai alat transportasi dan isyarat tentang ilham Allah kepada manusia untuk menciptakan -memproduksi- berbagai alat transportasi yang lebih baik dari masa turunnya ayat sehingga terus berkembang di masa mendatang (Shihab, 2000: 7, 188-191).

Menurut Quraish, penggunaan kata kerja bentuk mudâri' dalam tiga ayat ini merupakan isyarat pengulangan dan kesinambungan nikmat tersebut yang menuntut kesinambungan sikap syukur (Shihab, 2000: 7, 185-186). Hal tersebut juga memberikan arti bahwa aktifitas produksi manusia pun akan terus berkelanjutan agar ketersediaan barang tetap terjaga.

b. QS. al-Hadid/57: 25

Dan Kami menurunkan besi yang padanya (terdapat) kekuatan yang hebat dan berbagai manfaat bagi manusia. Dan supaya Allah mengetahui (dalam kenyataan setelah mengetahuinya dalam ilmu-Nya yang gaib) siapa yang menolong (agama)-Nya dan para rasul-Nya, padahal (Allah swt.) tidak dilihatnya. Sesungguhnya Allah Maha Kuat, lagi Maha Perkasa (Shihab, 2013: 541).

Kata "anzalnā" (turunkan) memiliki arti menciptakan atau menampakkan sesuatu yang tadinya tidak tampak. Pada catatan kaki, Quraish menyebutkan penemuan ilmu astronomi modern mengenai logam besi yang berada di bumi diturunkan dari bintang-bintang di angkasa luar (Shihab, 2013: 541). Merujuk kepada Tafsir al-Muntakhab (Shihab, 2000: 14, 48-49), besi memiliki keistimewaan yang dapat menunjang peradaban manusia, merupakan logam yang paling sesuai untuk bahan senjata, dan bahan baku berbagai macam industri berat dan ringan., serta termasuk zat atau komponen yang dibutuhkan oleh tumbuhan, hewan dan manusia (Lajnah, tt: 808). Hal ini memberikan isyarat kepada manusia untuk senantiasa menggali ilmu pengetahuan dan melakukan produksi akan hal-hal yang dimaksud -secara baik- untuk meningkatkan teknologi.

\section{Terjemah Quraish Shihab terhadap Ayat Al-Quran tentang Distribusi}

a. QS. al-Hasyr/59: 7

Supaya ia (harta rampasan itu) tidak hanya beredar di antara orang-orang kaya (saja) di antara kamu. Dan apa yang diberikan Rasul bagi kamu, maka terimalah ia dan apa yang dia larang kamu, maka tinggalkanlah, dan bertakwalah kepada Allah, sesungguhnya Allah sangat keras hukuman-Nya (Shihab, 2013: 546).

Distribusi ekonomi merupakan salah satu titik berat dalam pemecahan permasalahan ekonomi di mana dalam mekanismenya harus terwujud secara adil bagi seluruh masyarakat (Rozalinda, 2017: 131). Al-Quran menegaskan melalui ayat ini yang menurut Quraish, menunjukkan tentang fungsi sosial harta, sehingga Islam 
mengatur agar harta benda tidak hanya dimiliki dan dikuasai oleh sekelompok manusia -monopoli antar orang kaya saja- melainkan harus beredar untuk dinikmati oleh semua anggota masyarakat. Hal ini selaras dengan sistem etika alternatif yang berprinsip pada keadilan distributif di mana pembagian kekayaan, keuntungan, dan kerugian dijamin secara adil (Muhammad, 2004: 42-47). Konsep Islam menegaskan bahwa keseimbangan peredaran harta yang dimaksud dengan tetap memenuhi konsep kepemilikan pribadi. Hal ini menjadi prinsip dasar Islam dalam bidang ekonomi (Shihab, 2000: 14, 112-113), karena ketimpangan pembagian dapat menyebabkan kesenjangan ekonomi yang dapat memicu munculnya kejahatan dan kekacauan masyarakat (Rahman, 1995: 1, 35).

b. QS. al-Taubah/9: 34

Hai orang-orang yang beriman! Sesungguhnya banyak ahbar (para pemuka agama Yahudi) dan para rahib (para pemuka agama Nasrani) yang benar-benar makan harta orang dengan jalan yang batil dan mereka (juga) menghalang-halangi (manusia) dari jalan Allah. Dan orang-orang yang menyimpan emas dan perak dan tidak menafkahkannya pada jalan Allah, maka gembirakanlah mereka dengan azab yang sangat pedih.

Menurut Quraish, ayat ini bermaksud menunjukkan keburukan para pemuka agama Yahudi dan Nasrani -dua kelompok ini disebutkan dalam bentuk sisipan kalimat yang berfungsi sebagai penjelas maksud ayat- menyangkut kehidupan duniawi, yaitu sikap tamak, menumpuk harta, mengambil dengan cara batil, dan menghalangi manusia dari jalan Allah dengan berbagai cara, sedangkan pada kalimat berikutnya, "orang-orang yang menyimpan emas dan perak dan tidak menafkahkannya pada jalan Allah" merupakan kecaman yang ditujukan kepada orang-orang beriman yang kikir dan tidak membayar zakat (Shihab, 2000: 5, 551-552). Ayat tersebut, sebenarnya menjelaskan tentang larangan menimbun, memonopoli, menyelundupkan, mengambil keuntungan secara berlebih dan memusatkan kekuatan ekonomi pada satu tangan atau satu kelompok (Shihab, 2003: 411-412) sebagaimana etika bisnis yang seharusnya (Umar, 1997: 5-9).

Selain itu perlu dipahami juga bahwa orang yang mengumpulkan harta sebagai persiapan masa depan tidak termasuk dalam kecaman tersebut, karena kecaman ditujukan bagi yang mengumpulkan tanpa menafkahkannya di jalan Allah Swt dan kelak ia akan menerima adzab yang menimpa pada dahi, lambung, dan punggung (Shihab, 2002: 5, 552). Dalam hal ini, Islam sedari awal telah memiliki rambu-rambu, sedangkan pada era kini, terjadinya monopoli dan persaingan sempurna sangat tergantung dengan kebijakan pemerintah (Nopirin, 2008: 364-366). 


\section{Terjemah Quraish Shihab terhadap Ayat Al-Quran tentang Konsumsi}

a. QS. al-Baqarah/2: 168

Hai seluruh manusia! Makanlah yang halal, lagi baik dari apa (yang terdapat) di bumi, dan janganlah kamu mengikuti langkah-langkah setan; (karena) sesungguhnya ia setan) adalah musuh yang nyata bagi kamu (Shihab, 2000: 1, 354).

Sebelum menafsirkan ayat, Quraish menyatakan bahwa aktifitas konsumsi tidak terbatas yang bersifat jasmani semata, melainkan juga yang bersifat rohani. Ia menjelaskan secara rinci dalam tafsir al-Mishbah, bahwa QS. al-Baqarah/2: 168 merupakan lanjutan akan ajakan dan tuntunan kepada manusia untuk memakan makanan jasmaniyang halālan dan tayyiban setelah -pada ayat- sebelumnya berupa hidangan rohani (Shihab, 2000: 1, 354). Ajakan tersebut tidak terbatas kepada orang-orang yang beriman, melainkan kepada seluruh manusia, bahwa mereka telah dipersilahkan untuk menkonsumsi apapun apa yang ada di bumi, dengan syarat halal dan tayyib. Maka dari itu siapapun yang bermaksud memonopoli hasil-hasil bumi dengan cara merugikan orang lain -tidak halal-, ia telah menentang ketentuan Allah. Kehalalan dan ketayyibanan makanan pun harus diupayakan oleh manusia, karena tidak semua yang tersedia di bumi sudah mencapai dua standar tersebut (Shihab, 2000: 1, 354-355).

b. QS. al-Baqarah/2: 172, al-Nahl/16: 114 dan al-Mu'minun/23: 51

Hai orang-orang yang beriman! Makanlah dari rezeki yang baik-baik yang Kami anugerahkan kepada kamu dan bersyukurlah kepada Allah, jika kamu benar-benar hanya menyembah kepada-Nya (QS. al-Baqarah/2: 172).

Menurut Shihab, seruan pada ayat ini -tanpa menyebutkan kata "halal"berbeda dengan seruan pada QS. al-Baqarah/2: 168 di atas, di mana Allah pada kali ini menegaskan bahwa keimanan dalam hati orang yang beriman merupakan jaminan jauhnya mereka dari sesuatu yang tidak halal. Selain itu mereka diseru untuk bersyukur dengan penekanan yang sangat kuat, yaitu: jika kamu benar-benar hanya menyembah-Nya" (Shihab, 2000: 1, 359). Semakna dengan ayat ini, yaitu QS. al-Nahl/16: 114 dan al-Mu'minun/23: 51 akan tetapi pada ayat 51 terdapat anjuran yang berdeda, yaitu agar para rasul melakukan amal saleh.

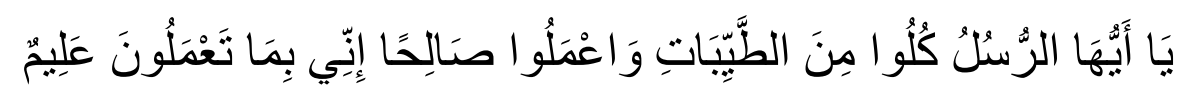

Wahai para rasul! Makanlah dari (makanan) yang baik-baik dan kerjakanlah amal saleh, sesungguhnya Aku Maha Mengetahui apa yang kamu kerjakan.

Ayat QS. al-Mu'minun 51 menghimpun para rasul ke dalam satu ajakan bersama. Ajakan pertama yaitu agar "memakan makanan yang baik-baik" 
(attayyibāt) yaitu yang tidak kotor dan sehat, rusak, tercampur najis, lezat, menentramkan, paling utama, sesuai dengan tuntutan agama, dan atau sesuai selera yang hendak memakannya selama tidak melanggar larangan agama (Shihab, 2000: 9, 198-200). Quraish berpendapat kata "kulü" tidak terbatas kepada aktivitas memakan makanan di mulut dan memprosesnya di perut, melainkan lebih luas yaitu segala aktivitas manusia (Shihab, 2000: 9, 198-199).

Ajakan kedua yaitu "kerjakanlah amal saleh," guna memelihara dan meningkatkan kualitas kemanusiaan dan menyukseskan tugas risalah mereka (Shihab, 2000: 9, 198). Menurutnya, ajakan makan sebagai pembuka ayat bermaksud untuk menegaskan bahwa para rasul tersebut adalah manusia -mereka makan dan minum-, menyindir umat -yang mengira bahwa rasul tidak pantas dari kalangan manusia- dan mengingatkan agar mereka tidak melupakan aspek kemanusiaan pada diri mereka. Selain itu, dua ajakan tersebut merupakan isyarat kepada rasul dan umat mereka agar menjaga kesucian lahir -diisyaratkan dengan makan- dan kesucian batin -diisyaratkan dengan amal saleh (Shihab, 2000: 9, 199).

c. QS. al-A'raf/7: 31

Hai anak cucu Adam! Pakailah pakaian kamu yang indah setiap (memasuki dan berada di) masjid, dan makan serta minumlah, dan janganlah berlebih-lebihan. Sesungguhnya Dia tidak menyukai orang-orang yang berlebih-lebihan (dalam segala hal).

QS. al-A'raf ayat 31 berbicara tentang anjuran mengkonsumsi hal apapun agar tidak berlebih-lebihan, baik pakaian, terlebih lagi dalam makan dan minum. Anjuran ini ditujukan kepada setiap manusia, terlepas apapun agama mereka, karena berkaitan dengan kesehatan badan (Shihab, 2000: 5, 72-73). Sedangkan dalam sudut pandang ilmu ekonomi, Quraish berpendapat bahwa sikap konsumtif atau boros dapat menyebabkan kelangkaan barang sehingga menimbulkan kenaikan harga dan ketidakseimbangan barang di pasar (Shihab, 2003: 412).

d. QS. al-A'raf/7: 32

Katakanlah (Nabi Muhammad saw.): "Siapakah yang mengharamkan perhiasan dari Allah yang telah Dia keluarkan untuk para hamba-Nya dan (siapa pula yang mengharamkan) yang baik-baik dari rezeki?" Katakanlah: "Ia adalah untuk orang-orang yang beriman (dan juga yang tidak beriman) di kehidupan dunia, (tetapi ia akan menjadi) khusus (untuk mereka yang beriman saja) pada Hari Kiamat." Demikianlah Kami menjelaskan secara rinci ayat-ayat (ketetapan-ketetapan hukum atau bukti-bukti kekuasaan Kami) kepada kaum yang mengetahui.

Ayat ini -dan ayat sebelumnya- sebenarnya ditujukan kepada kelompok Hummas yang mengharamkan pakaian biasa untuk thawaf dan makanan. Pada kalimat berikutnya Quraish menjelaskan maksud ayat menggunakan kalimat sisipan dalam 
tanda kurung, bahwa zinnah (perhiasan) dan tayyibät (rezeki yang baik-baik) Allah berikan kepada seluruh manusia, baik yang beriman dan tidak beriman, akan tetapi perhiasan atau kenikmatan tersebut di akhirat kelak akan dikhususkan bagi yang beriman saja. Rezeki yang baik tersebut sesuai dengan kondisi manusia sebagai salah satu jenis makhluk -memiliki jasmani dan rohani- maupun sebagai pribadi -anak, dewasa, wanita, pria, menderita penyakit tertentu, dan sebagainya- secara proporsional (Shihab, 2000: 5, 74-75). Menurut Quraish, kata "khāliṣatan” dapat dipahami dalam arti suci, yaitu kelak rezeki tersebut di Hari Akhir bebas dari apapun yang dapat menodainya, baik berupa kebebasan dari pengharaman, pembatasan, ketiadaan, kekurangan, persaingan memperebutkannya, persoalan mendapatkannya, juga kotoran dan hal yang dapat membahayakan sebagaimanya ketika di dunia (Shihab, 2000: 5, 76).

e. QS. al-Isra/17: 29

Dan janganlah engkau jadikan tanganmu terbelenggu ke lehermu (kikir), dan jangan (pula) engkau terlalu mengulurkannya (secara berlebih-lebihan), karena itu menjadikanmu duduk (tidak dapat berbuat apa-apa, lagi) tercela (oleh dirimu sendiri atau orang lain) dan (menyesal) tidak mempunyai kemampuan (karena telah kehabisan harta) (Shihab, 2013: 285).

Ayat ini memerintahkan manusia agar tidak kikir dan tidak longgar (berlebihan) dalam berinfak, memberi, dan memanfaatkan harta untuk kebutuhan sendiri. Sikap yang seharusnya adalah sikap pertengahan atau kewajaran antara keduanya (Rahman, 1995: 2, 22) untuk menjaga manusia dari keadaan tercela (maḥsüran) karena kehabisan harta (Shihab, 2000: 7, 454-455).

Ayat-ayat yang membahas tentang aktifitas konsumsi banyak menyinggung tentang aturan agar tidak berlebih-lebihan atau konsumtif. Dalam pandangan Quraish, sikap konsumtif tidak saja sebagai keburukan dan tindakan berlebihan yang dapat mengikat orang tersebut pada kesenangan dan kenimatan duniawi, sebagaimana pandangan para mufassir pada umumnya, melainkan karena berkaitan dengan perputaran roda ekonomi, di mana sikap konsumtif dapat mengakibatkan kelangkaan barang sehingga berimbas pada ketidakseimbangan dan kenaikan barang (Shihab, 2003: 412).

Sedangkan Muhammad al-Ghazali, aktifitas tersebut merupakan sarana memamerkan kekayaan seseorang dan dapat mendorong sikap gemar berlebihan yang akan semakin mengikatnya kepada kesenangan duniawi (al-Ghazali, 2001: 147). Tindakan berlebihan yang dilarang oleh Allah Swt pun tidak saja membahayakan diri sendiri melainkan bagi orang lain dan lingkungan sekitar. 
Allah bahkan tidak menyukai manusia yang bersikap sombong dan angkuh, meskipun secara fisik ia tampak jujur dan saleh dengan mengenakan pakaian tertentu (al-Ghazali, 2001: 147-148).

\section{SIMPULAN}

Kajian ini menunjukkan bahwa urgensi penerjemahan al-Quran ke dalam bahasa non Arab beriringan dengan problematika penerjemahan itu sendiri, karena al-Quran adalah kitab suci yang tidak dapat diperlakukan dan diposisikan seperti teks pada umumnya. Hal tersebut menuntut Quraish sebagai ahli tafsir dan terjemah al-Quran melakukan upaya penerjemahan yang tidak keluar dari koridornya dengan mengikuti aturan penerjemahan ulama al-Azhar.

Penerjemahan al-Quran, menurut Quraish, tidak sama sebagaimana menerjemahkan teks-teks pada umumnya dengan cara mengalihbahasakan kata dalam bahasa sumber (Bsu) ke kata dalam bahasa sasaran (Bsa), melainkan merupakan penerjemahan terhadap makna-makna yang dikandung oleh ayat, sehingga Quraish menggunakan metode tafsiriyah di mana proses penerjemahannya berbasis tafsir, dapat juga disebut dengan metode ma'nawiyah (makna) yang tetap memperhatikan tafsir ayat.

Berkenaan dengan terjemah ayat-ayat produksi, Quraish memudahkan maksud ayat dengan menyisipkan keterangan tambahan pada terjemahnya sebagaimana yang dilakukan pada ayat lainnya. Ia menjelaskan -dalam karya al-Mishbah- tentang nikmat-nikmat Allah bagi manusia yang akan dimanfaatkan secara berkesinambungan, hal tersebut menyiratkan bahwa kegiatan produksi pun akan terus berkelanjutan mengikuti tuntutan kebutuhan hidup manusia. Sehingga hendaknya diiringi -secara berkesinambungan- dengan sikap syukur manusia atas rahmat Allah Swt yang telah menciptakan dan melimpahkan -nikmat berupa- bahan-bahan produksi bagi manusia. Produksi yang berkelanjutan pun pada dasarnya menuntut manusia untuk arif dan bijaksana dalam penyediaan dan pengolahan bahan dasar, sehingga tindakan eksploitasi bahan dasar perlu dihindari karena akan merugikan manusia itu sendiri.

Berkenaan ayat-ayat tentang distribusi, Quraish menyinggung tentang fungsi sosial harta dalam tafsirnya dan beberapa aturan terkait. Ayat-ayat tersebut memberikan kesimpulan tetang prinsip distribusi, yaitu larangan memonopoli, menimbun, menyelundupkan, mengambil keuntungan secara berlebihan dan memusatkan kekuatan ekonomi pada satu tangan atau satu kelompok. Sedangkan dalam bidang konsumsi, al-Quran memberikan rambu-rambu yang dapat dijadikan prinsip, yaitu berupa: mengkonsumsi semua hal yang halal dan tayyib, menjauhi godaan setan, memakan rezeki yang baik dan banyak bersyukur, tidak berlebihan -agar tidak mengikatkan 
manusia degan kehidupan duniawi dan menjaga ketersediaan barang di pasar-, dan terus beramal saleh.

Meskipun terjemah ayat memberikan pemahaman makna yang masih terbatas dan tidak mendalam sebagaimana tafsirnya, akan tetapi terjemah ayat tetap dibutuhkan untuk membantu pemahaman secara singkat pada tahap awal. Ayat-ayat al-Quran yang telah dikaji memberikan pemahaman tentang konsep dan empat prinsip ekonomi, yaitu prinsip tauhid, keseimbangan, kehendak bebas, dan tanggungjawab (Shihab, 1998: 409). Prinsip-prinsip tersebut hendaknya senantiasa diterapkan dalam setiap aktifitas produksi, distribusi, dan konsumsi sehingga berdasarkan pada ruh al-Quran.

\section{DAFTAR PUSTAKA}

Abdul-Raof, H. (2013). Qur'an translation: Discourse, texture and exegesis. Routledge.

Abdusshamad, S. (2015). Ayat Tentang Distribusi Serta Relasi Kaum Kaya \& Miskin. Al-Iqtishadiyah: Ekonomi Syariah dan Hukum Ekonomi Syariah, 2(2).

Al-'Alūsy, Jalāluddin bin Ṭāhir. (2007). Aḥkām Tarjamah al-Qur'ān al- 'Karìm, (Beirut: Dār Ibnu Hazm, cet. I.

al-Ghazali. Muhammad. (2001). A Thematic Commentary on The Qur'an, translated by Ashur A. Shamis, Malaysia: Islamic Book Trust.

al-Razi. Fakhruddin, Mafätih al-Ghaib, dalam Syamela Library 2.11.

al-Zahabi. Muhammad Husein. (2000). Al-Tafsïr wa al-Mufassirūn. Kairo: Maktabah Wahbah.

al-Zarqanī. Muhammad 'Abdul 'Azīm. (1995 M/ 1415 H). Manāhil al-'Irfān fí 'Ulūm al-Qur'ān, Beirut: Dār al-Kitāb al-'Arabì, cet. I.

Arichea. Daniel C. (1990). Theology and Translation: The Implication of Certain Theological Issues to the Translation Task. Ed. Philip C. Stine, Bible Translation and the Spead of the Church the Last 200 Years, Netherlands: E. J. Brill.

Baidan. Nashiruddin (1998). Metodologi Penafsiran Al-Quran, Yogyakarta: Pustaka Pelajar.

Baihaki, E.S. (2017). Penerjemahan Al-Qur'an: Proses Penerjemahan al-Qur'an di Indonesia. Jurnal Ushuluddin, 25(1), pp.44-55.

Charlesworth, M. (2012). Translating religious texts. Sophia, 51(4), pp.423-448.

Darussalam, A.Z., Malik, A.D. and Hudaifah, A. (2017). Konsep Perdagangan dalam Tafsir Al-Mishbah (Paradigma Filsafat Ekonomi Qur'ani Ulama Indonesia). Al Tijarah, 3(1), pp.45-64.

Eggen, N.S. (2016). Universalised versus Particularised Conceptualisations of Islam in 
Translations of the Qur'an. Journal of Qur'anic Studies, 18(1), pp.49-91.

Esposito. John L. (1995). The Oxford Encyclopedia of ther Modern Islamic World, New York: Oxford University Press.

Fauziah, C. (2017). At-Tijarah (Perdagangan) Dalam Alquran (Studi Komparatif Tafsir Jami 'Li Ahkam Alquran dan Tafsir Al-Mishbah). Jurnal At-Tibyan: Jurnal Ilmu Alquran dan Tafsir, 2(1), pp.76-96.

Hadi. Sutrisno. (2014). Metodologi Research, Yogyakarta: Andi Offset.

Haleem, M.A. (2018). The Role of Context in Interpreting and Translating the Qur'an. Journal of Qur'anic Studies, 20(1), pp.47-66.

Hanafi. Muschlis M. (2011). Problematikan Terjemahan al-Qur'an Studi pada Beberapa Penerbitan al-Qur'an dan Kasus Kontemporer, Suhuf, Vol. 4, No. 2, Lajnah Pentashihan Mushaf Al-Quran Badan Litbang dan Diklat Kemenag RI.

http://www.pktafsirquran.com/2017/04/daftar-lengkap-karya-buku-quraish-shihab.html, diakses 18 Oktober 2018, pukul 14.00 WIB.

Istianah, I. (2016). Dinamika Penerjemahan Al-Qur'an: Polemik Karya Terjemah Al-Qur'an HB Jassin dan Tarjamah Tafsiriyah Al-Qur'an Muhammad Thalib. Maghza: Jurnal Ilmu Al-Qur'an dan Tafsir, 1(1), pp.41-56.

Istianah. (2015). Fenomena Alih Bahasa Al-Qur'an Kritik atas Koreksi Muhammad Thalib Terhadap Terjemah Al-Qur'an Kemenag RI. Jurnal Suhuf, Vol 8, pp 203-231.

Iswadi, M. (2013). Pemikiran Quraish Shihab Tentang Ayat-Ayat Ekonomi. Fenomena, 5(2).

Lajnah al-Quran wa Sunnah. Majelis A'la. (tt). al-Muntakhab fi Tafsìr al-Qurān al-Karim, Doha: Dar al-Saqafah.

Muhammad, M. (2018). Dinamika Terjemah Al-Qur'an (Studi Perbandingan Terjemah Al-Qur'an Kemenerian Agama RI dan Muhammad Thalib). Jurnal Studi Ilmu-ilmu Al-Qur'an dan Hadis, 17(1), pp.1-24.

Muhammad. (2004). Etika Bisnis Islami. Yogyakarta: UPP AMP YKPN.

Newmark. Peter. (1988). A Textbook of Translation, New York: Prentice Hall.

Nopirin. (2008). Pengantar Ilmu Ekonomi Makro dan Mikro, Cet. 7. Yogyakarta: BPFE Yogyakarta.

Pink, J. (2015). 'Literal Meaning'or 'Correct 'aqīda'? The Reflection of Theological Controversy in Indonesian Qur'an Translations. Journal of Qur'anic Studies, 17(3), pp.100-120.

Rahman, Afzalur. (1995). Doktrin Ekonomi Islam. Terj. Soeroyo, Nastangin. Yogyakarta: Dana Bhakti Wakaf. 


\section{Islãmadîna

Rohmana. A Jajang. (2015). Terjemah Puitis Al-Qur'an di Jawa Barat Terjemah Al-Qur'an Berbentuk Puisi Guguritan dan Pupujian Sunda, Șụuf, Vol. 8, No. 2, Lajnah Pentashihan Mushaf Al-Quran Badan Litbang dan Diklat Kemenag RI.

Rozalinda. (2017). Ekonomi Islam: Teori dan Aplikasinya pada Aktivitas Ekonomi. Cet. 4. Depok: Rajawali Pers.

Saeed. Abdullah, 2016. Paradigma, Prinsip dan Metode Penafsiran Kontekstualis al-Quran, terj. Lien Iffah Naf'atu Fina dan Ari Henri, Yogyakarta: Lembaga Ladang Kata, cet. 2.

Shihab. M. Quraish. (2000). Tafsir al-Mishbah Pesan, Kesan dan Keserasian al-Quran, Ciputat: Penerbit Lentera Hati, Cet. I.

Shihab. Quraish. (2003). Wawasan al-Quran: Tafsir Maudhui atas Pelbagai Persoalan Umat, Bandung: Mizan, Cet. XIV.

Shihab. Quraish. (2015). Kaidah Tafsir: Syarat, Ketentuan, dan Aturan yang Patut Anda Ketahui dalam Memahami al-Quran, Tangerang: Lentera Hati, cet. 3.

Suma. Muhammad Amin. (2000). Pengantar Tafsir Ahkam, Jakarta: PT RajaGrafindo Persada, Cet. 2.

Syahputra, R. (2014). Prinsip dan Landasan Ekonomi Islam M. Quraish Shihab. ECOBISMA (Jurnal Ekonomi, Bisnis dan Manajemen), 1(1), pp.67-80.

Thalib. Muhammad. (2011). Al-Qur'anul Karim: Tarjamah Tafsiriyah, Yogyakarta: Ma'had an-Nabawy, cet. II.

Umar Shihab. (2005). Kontekstualitas Al-Quran Kajian tematik Atas Ayat-ayat Hukum dalam Al-Quran, Jakarta: Penamadani, cet. III, hlm. 295. dalam Quraish Shihab, "Etika Bisnis dalam Wawasan Al-Quran", dalam Jurnal Ulum al-Qur'an, No. 3 VII/1997.

Wild, S. (2015). Muslim Translators and Translations of the Qur'an into English. Journal of Qur'anic Studies, 17(3), pp.158-182.

Zulfikar, A. (2017). Konsep At-Tijarah dalam Tafsir Al-Mishbah Karya M. Quraish Shihab. Annur: Journal Study Science of the Al-Quran and It's Interpretation, 1(1), pp.14-20. 